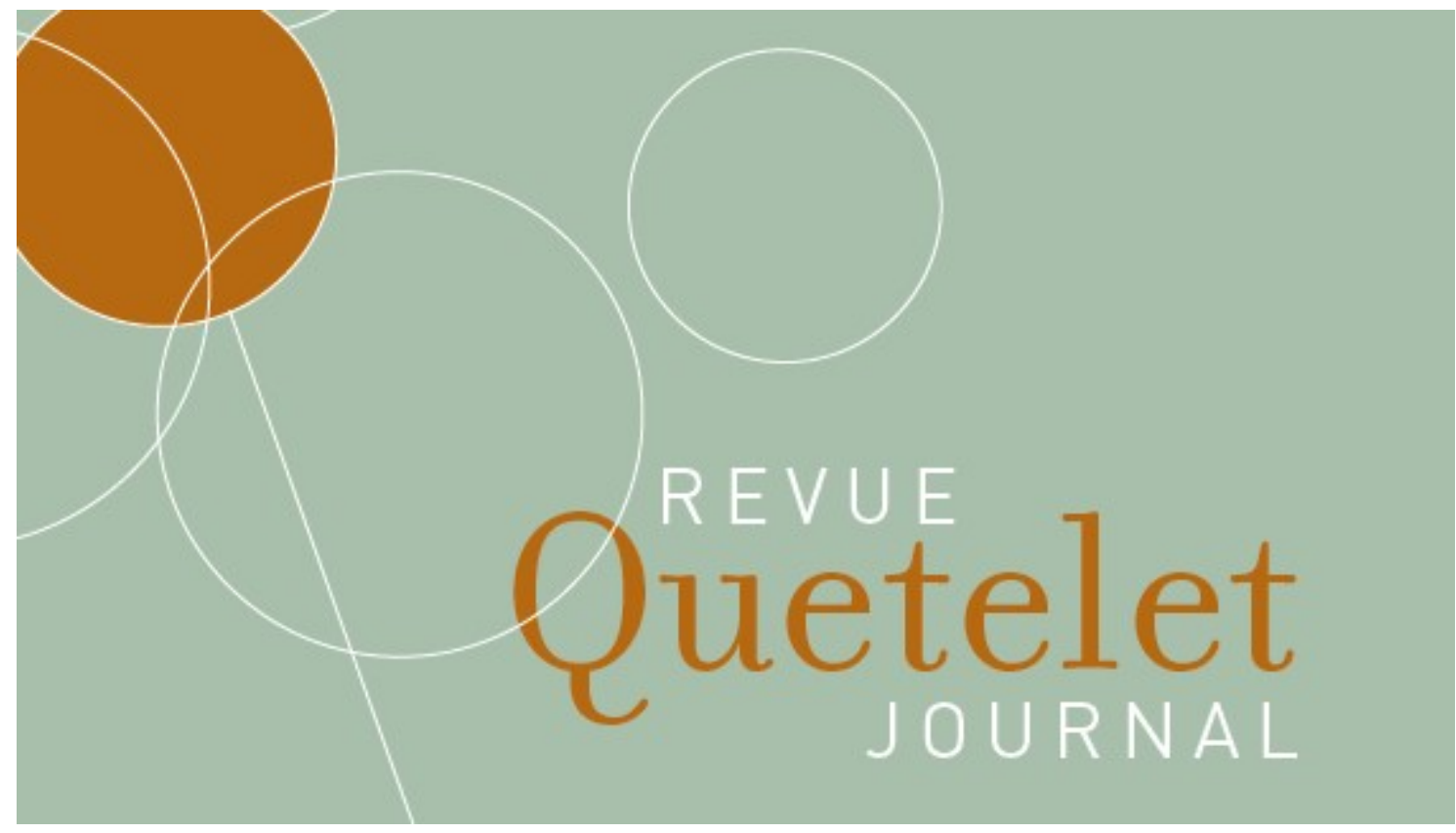

Vol. 5, $n^{\circ} 2$, octobre 2017, pp. 37-67

DOI : 10.14428/rqj2017.05.02.02

ISSN: 20349378

\title{
Education and marriage: The shift from hypergamy to hypogamy in Belgium, a 20th century cohort analysis
}

Eli Nomes

Jan Van Bavel

(C)2017 Eli Nomes, Jan Van Bavel

This work is licensed under a Creative Commons Attribution-NonCommercial 4.0 International License. You can share, adapt the material for non-commercial purposes provided that you give appropriate credit and indicate if changes were made. For details see https://creativecommons.org/licenses/by-nc/4.0/

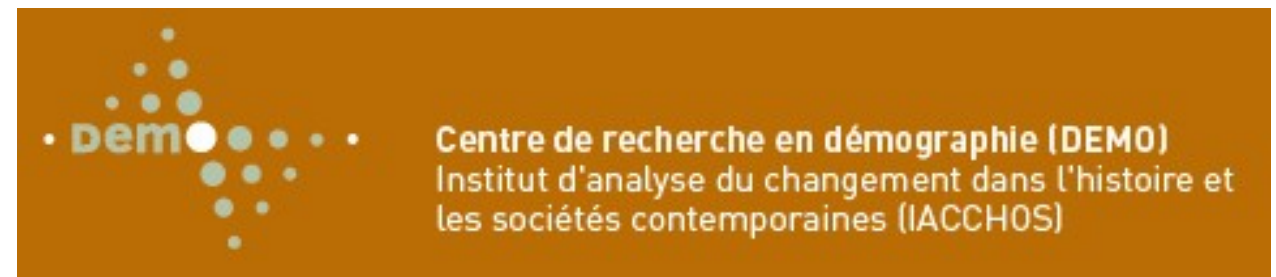





\title{
Education and marriage: The shift from hypergamy to hypogamy in Belgium, a 20th century cohort analysis
}

\author{
ELI NOMES \\ JAN VAN BAVEL ${ }^{1}$
}

\begin{abstract}
Résumé
L'une des principales tendances sociales du 20e siècle est l'augmentation de la scolarisation. En utilisant des informations rétrospectives détaillées des recensements de 1981 et de 2001, cet article étudie comment cette augmentation est associée aux grandes tendances de la nuptialité en Belgique. Nous nous concentrons spécifiquement sur l'évolution de l'équilibre entre les sexes à l'école et comment il est lié à la probabilité de se marier et au calendrier du mariage ainsi qu'aux modèles d'appariement des couples selon le niveau d'instruction. Notre analyse empirique montre que pour les cohortes nées dans la première moitié du 20ème siècle, le mariage est devenu plus universel, se produisant à un âge plus précoce, et plus souvent hétérogame en terme de scolarisation. Dans les cohortes plus jeunes, lorsque le niveau d'instruction des femmes a rattrapé celui des hommes, l'âge au mariage et le degré d'homogamie ont de nouveau augmenté. L'homogamie est restée dominante dans l'ensemble mais, si les femmes jusqu'aux cohortes des années 1950 ont eu tendance à épouser des hommes au moins aussi instruits qu'elles-mêmes, les femmes des cohortes plus jeunes ont eu tendance à épouser des hommes qui ne sont pas plus instruits qu'elles-mêmes. L'hypogamie est maintenant le deuxième modèle le plus commun, après l'homogamie. En contrôlant dans un modèle log-linéaire les changements dans la distribution du niveau d'instruction, nous constatons qu'une partie des changements dans l'appariement des couples en Belgique peut s'expliquer par des changements dans les préférences selon le niveau d'instruction du partenaire. Enfin, nous trouvons que les mariages hypogames ont tendance à se contracter à des âges plus tardifs que les mariages homogames ou hypergamiques.
\end{abstract}

Mots-clés

Nuptialité, scolarisation, hypogamie, hypergamie, homogamie, Belgique, analyse de cohorte.

1. Centre for Sociological Research, KU Leuven, Belgium. 


\begin{abstract}
One of the key social trends of the 20th century has been the expansion of participation in education. Using detailed retrospective information from the 1981 and 2001 censuses, this paper investigates how this expansion is associated with major trends in nuptiality in Belgium. We focus specifically on the changing gender balance in education and how this is related to the likelihood and timing of marriage and to patterns of educational assortative mating. Our empirical analysis shows that marriage was getting more universal, happening at an earlier age and more often heterogamous in term of education over the cohorts born in the first half of the 20th century. In younger cohorts, when women's levels of education caught up with men's, the age at marriage as well as the degree of homogamy increased again. Homogamy remained dominant throughout, but while women tended to marry men who were at least as highly educated as themselves until the 1950s cohorts, in more recent cohorts, women have tended to marry men who are at most as highly educated as themselves. Hypogamy is now the second most common pattern, after homogamy. Controlling for changes in the distribution of educational attainment by applying a log-linear model, we find that part of the changes in assortative mating in Belgium may be explained by changes in mate preferences regarding education. Finally, we find that hypogamous marriages tend to be contracted at later ages than homogamous or hypergamous ones
\end{abstract}

\title{
Keywords
}

Nuptiality, education, hypogamy, hypergamy, homogamy, Belgium, cohort analysis.

\section{Introduction}

In Belgium as elsewhere, the institution of marriage has been transformed over the course of the 20th century. The rapid change in the social and economic dimensions of everyday life, for example in education, economic opportunities and gender relations, has unmistakably left its mark. Some of the resulting changes are very obvious. At least on the surface, romantic love replaced convenience and economic interests as the main reason to get married (Coontz, 2005). The proportion of marriages celebrated in the Church declined from about 90\% in 1967 to less than 30\% in 2006 (Botterman, Hooghe, 2012). Divorce became an acceptable and normalized practice in Belgium and so did unmarried cohabitation.

So marriages in Belgium have become more about love, more secular, less stable and less imperative. In this paper we want to track the evolution of marriage among generations born in 20th century Belgium with regards to three fundamental aspects of the union formation process: who, when 
and whom. Who married? When did they get married? And who married whom?

An old and very robust finding from sociological research is that «like marries like» in terms of social background (Bozon, 1991; Kalmijn, 1998; van Leeuwen et al., 2005; Van de Putte, 2005; Schwartz, 2013). Actually, marriage is often argued to play an important role in the formation and maintenance of social class boundaries (Van de Putte, 2005). While homogamy («like marries like») contributes to the reproduction of the existing stratification, heterogamy (i.e., marrying with someone from a different social class) implies that class boundaries are permeable to some extent. «Marrying up» may be an effective way to achieve social mobility that stretches to the next generation, when the socially mixed marriage produces children. Therefore, the degree of heterogamy is often used as an indicator of the degree of openness of a society's social stratification (Glass, 1954; Kaelble, 1981; van Leeuwen et al., 2005; Van de Putte, 2005; Schwartz, 2013).

Although social class background continues to play an important role in the question of who marries whom, the 20th century has brought along a new dimension: education. One of the crucial social trends of the 20th century was indeed the expansion of participation in education, both for men and women (Meyer et al., 1992; Schofer, Meyer, 2005). Education increasingly became an important dimension of the socio-economic structure. Even though the chances to obtain an advanced educational degree continue to be strongly affected by parental social class (Shavit, Blossfeld, 1993; Bukodi, Goldthorpe, 2012), having an adequate diploma became a conditio sine qua non for pursuing a growing range of professions.

Consequently, education emerged as an increasingly important social dimension in the union formation process, too (Schwartz, 2013; Mäenpää, 2014). However, the educational expansion did not happen at the same time and with the same speed for men as it did for women. In the late nineteenth and first half of the twentieth century, the expansion of education applied predominantly to men. University-level education in particular was an almost exclusive male domain. Yet, in the second half of the twentieth century, women started to catch up with men (Meyer et al., 1992; Schofer, Meyer, 2005), and in the last quarter of the twentieth century, women obtained more education and more often completed successfully advanced degrees in a growing number of Western (as well as non-Western) countries (Schofer, Meyer, 2005; Van Bavel, 2012; Grow, Van Bavel, 2015). 
Crucial in the story of marriage, education and educational assortative mating is the evolution of gender relations. The position of the woman within the couple, within the household and within society was constantly evolving during the 20th century, though not always in the same direction. In the first half of the century, the picture we now regard as traditional was being formed: female homemaker, male breadwinner (Janssens, 1997). If anything, women were being pushed out of the labour market, into their homes. At the same time, relatively high educated women became more and more common. How did this play out in the marriage market? Only as the gender balance in education started to shift in the second half of the century, the so-called traditional gender roles and relations in general really started to get seriously challenged (Goldscheider et al., 2015). How was this reflected in marriage patterns? When did marriages between a highly educated wife and lower educated husband really become prevalent?

This paper investigates how the big expansion of education is associated with major trends in nuptiality in Belgium. Considering that education has become a key determinant of socio-economic wellbeing in the twentieth century, we investigate how the expansion of education was associated with marriage patterns, focusing mainly on educational assortative mating. We expect that homogamy has emerged as the dominant pattern among the younger cohorts, as is the case in for example the U.S.A. (Mare, 1991). First however, we want to provide clear descriptions of cohort trends in educational attainment, and of the likelihood and timing of marriage, both for men and women, given educational attainment. A comprehensive account of these trends is still lacking in the literature. How did the expansion of education by gender play out in the Belgian context? What have been the key trends in the timing and likelihood of marriage in Belgium? Second, as the main contribution of this paper, we want to describe how patterns of educational assortative mating have evolved in Belgium. While recent research has given us a clear idea of the contemporary patterns of assortative mating in Belgium, a historical account of how these patterns emerged is still missing. Do we see the changing composition of the Belgian population by education reflected in educational pairings? To what extent do the observed patterns result from changing mating preferences? And how does his and her education relate to the timing of union formation? 


\section{Data and methods}

To analyse cohort trends in Belgian nuptiality, we use the extensive individual-level information of the Belgian censuses of 1981 (Willaert, Deboosere, 2008) and 2001 (Deboosere, Willaert, 2004). The census of 1981 is used for cohorts born between 1910 and 1939, the census of 2001 is used for cohorts born between 1940 and 1975 . Together they offer us some insight in the lives of 8'314'501 persons born between 1910 and 1975. Although these censuses contain rich information on education and on marriage- and childbearing histories, there are some limitations given the quality and the retrospective nature of the data (Van Bavel, 2013). While both censuses offer the same type of information, the quality of the data differs quite a lot, especially with regards to the two key domains that are of interest for this paper: education and nuptiality. Educational attainment is expressed by a five-category variable, ranging from «at most primary» to "university», based on either the years an individual spend in school or on the highest diploma he obtained. However, this information is missing for $7 \%$ of the individuals of the 2001 census, compared to only $1 \%$ in the 1981 census. Insofar as non-response is negatively associated with educational attainment, this will result in overestimation of the share of the higher-educated and their nuptiality characteristics, especially in the cohorts for which we use the census of 2001. Since immigrants make out a large part of the low educated group, this also hampers our ability to correctly assess the impact of migration on marriage patterns.

With regards to marriage, there are different issues. Both in 1981 and 2001, apart from present union status, only women were asked about their marriage histories. While it is therefore fairly straightforward to calculate the mean age at first marriage or the proportion ever married at a certain age for women, this is not the case for men. Apart from their current marital status, we only know something about their marriages indirectly, through connecting them to their wives. However, we can only link husbands and wives with each other if they still lived together at time of the census. If by this time a woman was widowed, divorced or separated from her husband, we cannot link them. From the information about the current marital status, we know that this is the case for about $20 \%$ of ever married men and women, although this percentage gets as high as $45 \%$ among the oldest cohorts, born in the early 1910s. Some bias due to selection effects with regards to mortality is therefore unavoidable, given the social gradient of mortality (Gadeyne, Deboosere, 2002). If there is furthermore a link between divorce and assortative mating, which is 
quite plausible (Blossfeld, 2014; Frimmel et al., 2013), divorce could also introduce some bias. This is especially the case for the census of 2001, which has information on cohorts among which divorce had become much more common.

When we are able to make the connection between husband and wife, we can calculate the age at marriage for the husband, but we have no way of knowing whether or not he might have been married to someone else before. Consequently, we have no information on the age at first marriage for men, and we can only compare the age of a woman who marries for the first time, and her husband who might or might not be marrying for the first time himself.

To be able to describe the likelihood of marriage for men, we need to impute age at marriage information for the men we could not connect to their wives. Otherwise, missing age at marriage information of $20 \%$ or more of ever married men would likely result in a large underestimation of the proportion of men married by the age of 40 . We therefore randomly connect (once) married men to (once) married women, given cohort and educational attainment specific probabilities based on the properly connected couples in the data. For example: a divorced man born in 1930 with a university degree is randomly connected to a wife (and her date of marriage) of a certain age and educational level, given a probability distribution based on all men born in 1930 with a university degree who are in a woman's first marriage. The group of marriages on which we base our probability distributions includes men who are already in their second (or higher order) marriage. It is not an unlikely scenario that older divorced or widowed men remarry younger women who may not have been married before. This could lead to a underestimation of the proportion of men married by the age of 40 . However, the percentage of men older than 40 marrying women who were not married before is at most $1 \%$ for the men who were the oldest at the time of the census, and decreases over the cohorts to $0 \%$ for those who were 40 at the time of the census. Any distortion of the likelihood of marriage for men should therefore be rather small. To describe patterns of educational assortative mating, we do not use these randomly connected couples, as they just mirror the patterns already present in the data. Instead, we compare the educational attainment of the husband and wives of the properly connected couples and we chart the evolution of the prevalence of the different resulting assortative mating «types». We distinguish between low educated and medium to highly educated homogamous couples, hypergamous couples where the husband has a higher educational level than the wife, and hypogamous couples where it is the other way around. 
To see whether changes in the observed assortative mating patterns are merely due to changes in the educational distributions or whether they are to some extent due to changes in the union formation process itself, we apply a log-linear model. A particular problem with studying assortative mating is the problem to isolate trends in preferences for assortative mating from changes in the marginal distribution of educational levels (Liu, Lu, 2006; Kalmijn, 1991; Mare, 1991, 2014). Say you have a population of 100 men and 100 women, of which only 50 men and 10 women are highly educated who all prefer a partner with the same level of educational attainment. Then only 10 out of 50 highly educated men (or $20 \%$ ) will be able to find such a partner, while 10 out of 10 (or $100 \%$ ) highly educated women are able to do so. The resulting difference in the rate of homogamy between highly educated men and women is completely due to the different (marginal) distribution of educational attainment and not to different mating preferences. If at a later point in time, there are now 50 highly educated women and the number of highly educated men has stayed the same, $100 \%$ of those men are now able to marry homogamously. The homogamy rate for these men has then been multiplied by five, only because the number of women with a high educational attainment has grown.

Hence, changes in the relative number of educationally homogamous marriages do not necessarily only reflect changes in preferences for assortative mating or changes in the social structure that lead to certain assortative mating outcomes, but also in the marginal distribution of educational attainment. Both factors are important: the fact that the marginal distribution of educational attainment has changed so much during the $20^{\text {th }}$ century is a big part of the story. To get a grip on trends in educational assortative mating preferences, however, we need to be able to separate changes due to the changing marginal distribution and changes due to changing preferences. We therefore need a measure that can isolate these two factors. A method that is often used is a log-linear model (Schwartz, 2013), which estimates the cell frequencies of a contingency table, and more precisely compares the odds of being on the diagonal (i.e., the odds of being in a homogamous marriage) with the odds of being off the diagonal (a heterogamous union), net of the marginal distributions. Log-linear models for square contingency tables have therefore often been used to provide estimates of changes in the association between couples' educational characteristics while controlling for changes in their marginal distribution. Kalmijn (1991) and Mare (1991) applied the method in their seminal articles on patterns of assortative mating in the US, but also for example Birkelund and Heldal (2003) in an article about 
assortative mating in Norway or more recently Schmidt \& Winter (2008) in their article on educational assortative mating in Germany.

Let $\mu_{i j t}$ be the expected frequency of marriages between a husband with educational attainment $i$ and a wife with educational attainment $j$ and birth year $t$, and assumed to be an independent observation of a Poisson random variable. Then the diagonal log-linear model can be specified as a generalized linear model as follows:

$$
\log \left(\mu_{i j t}\right)=\lambda+\lambda_{i}+\lambda_{j}+\lambda_{t}+\lambda_{i t}+\lambda_{j t}+\delta_{i j t}
$$

$\lambda$ is the overall intercept. $\lambda_{i}$ and $\lambda_{j}$ are parameters capturing the marginal distribution of the educational attainment of husbands and wives, respectively. $\lambda_{t}$ is the overall cohort effect. $\lambda_{i t}$ and $\lambda_{j t}$ capture the changes over cohorts of these marginal distribution. $\delta_{i j t}$ is 0 for all cells where the educational attainment $i$ of the husband is different from the educational attainment $j$ of the wife. On the diagonal, when $i=j$, it captures how the corresponding expected frequency deviates from what can be expected from the other terms; it isolates the degree of homogamy that is not explained by the marginal distributions of educational attainment for each cohort and educational level. To find the maximum likelihood estimators of all these parameters, we apply Iterative Reweighted Least Squares (Agresti, 2002).

\section{The expansion of education in Belgium}

The expansion of participation in education is one of the main social changes of the 20th century in the Western world. It is generally seen as having exerted a positive influence on equality and social mobility (Breen, 2010) as well as economic prosperity (Lutz et al., 2008). Belgium, although lagging behind somewhat compared to its neighbouring countries, participated as well in this trend.

During the nineteenth century, the majority of the Belgian population already got access to at least some primary education, reducing illiteracy around 1900 among both men and women to rates below 10\% (Matthijs, 2001). In the 20th century more and more people gained access to secondary education and eventually, in the second half of the century, even to higher education (Vanderstraeten, 1996). This expansion was driven by socio-economic mechanisms and diffusion processes as well as by 
public policy interventions (Ballarino et al., 2013). For instance, the relatively late introduction of compulsory education until the age of 14 in Belgium in 1914 affirmed and strengthened an evolution that was already well underway before that (de Vroede, 1970), as did the extension of compulsory education until the age of 18 in 1983 (Ronsijn, 2014).

Compared to most neighbouring countries, the expansion of education in Belgium was lagging behind in its first stage. In 1950 for example, the average Belgian over 25 had a year of schooling less (5.84) than the average Dutchman (6.89) (Cohen, Soto, 2001), reflecting the relative arduous embrace of universal primary education. Belgium however caught up in the second stage (when secondary education became the norm) and became a vanguard country in Europe during the last stage (towards tertiary education, see Barro, Lee, 2001), when higher relative wages and more job security for the relatively highly educated started to drive up demand for higher education (Duchesne, Nonneman, 1998). Ronsijn (2014) finds that the average age at which people leave school rose from about 13 in 1910 to almost 21 in 1990. The IIASA back-projection of educational distribution for Belgium (Lutz et al., 2007) show that the percentage of 20 to 64 year olds who have at most completed primary education dropped from $50 \%$ for men and almost $60 \%$ for women in 1970 to $19 \%$ and $22 \%$ respectively in 1995. By 1995, there were more women and men who completed tertiary education (i.e., university level as well as non-university post-secondary education) than primary education only. Based on census data, we calculated that by the middle of the 1990s a quarter of the population was highly educated, confirming the IIASA projections. Towards the end of the decade, women surpassed men in terms of tertiary education, so that since 1998, for the first time in history, there are more highly educated women than men.

These gender differences are of special interest for this paper. Advanced education clearly did not reach everybody at the same time and to the same extent. Apart from gender differences, social and spatial differences in the expansion of education too have been studied extensively (see for example Vanderstraeten et al., 2001). It has become clear that while women were considerably less educated than men in the past, they have caught up with men in recent years (Schofer, Meyer, 2005). In Belgium, as elsewhere, there are now indeed more women than men who obtain a higher degree (Vincent-Lancrin, 2008; Grow, Van Bavel, 2015). As noted earlier, men born in the early 1900 s were indeed twice as likely to receive higher education than their female contemporaries.

Figure 1 plots the cohort trends based on our census data that underlie these gender differences in the expansion of education. For generations 
born at the beginning of the century, completing education beyond the primary school was exceptional, both for men and women. Only $4 \%$ of men born in the first decade of the 20 th century and $2 \%$ of women completed tertiary education. In the generations born in the middle of the century, the number of men and women with a degree in tertiary education had already increased to $18 \%$ and $17 \%$ respectively. Taking into account that these numbers are calculated on the basis of retrospective census data and given the inverse relation between education and mortality (Gadeyne, Deboosere, 2002), if anything, these trends underestimate the true amount of growth (since low educated people from the older cohorts will be more likely to have died before the census than the highly educated).

FigURE 1 Distribution of educational attainment by gender and cohort, birth cohorts 1900-1975

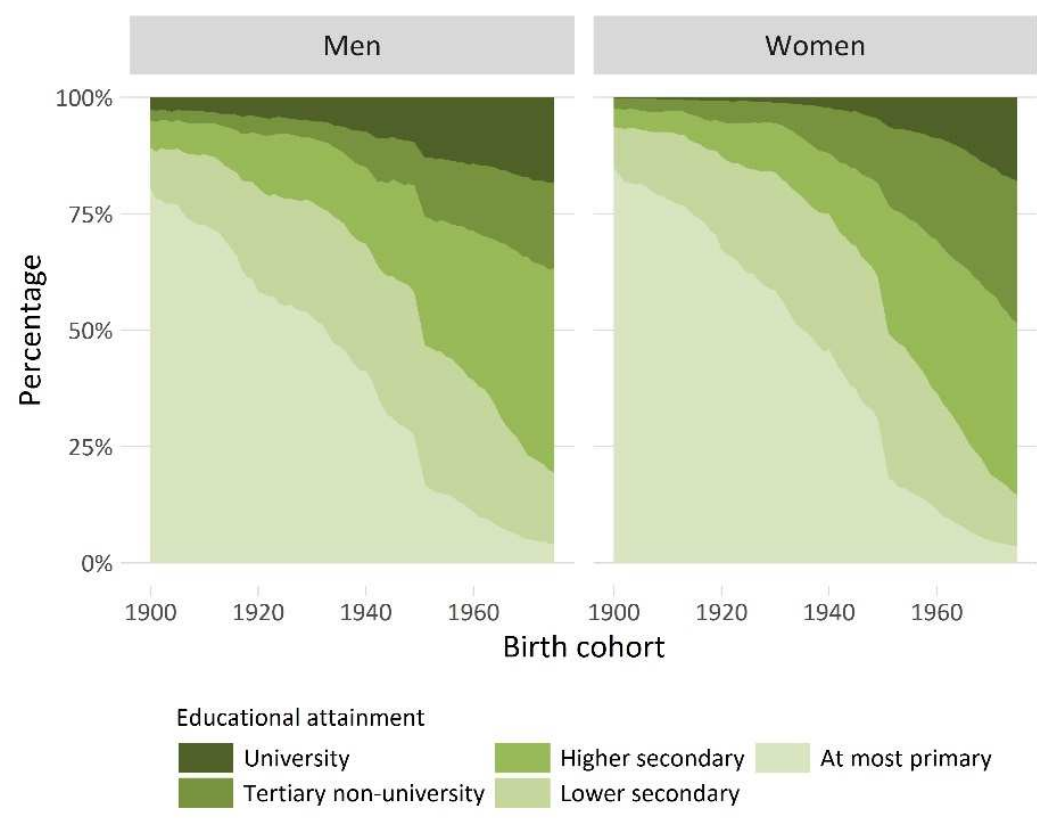

Source: Belgian census of 1981 (cohorts born between 1900 and 1950) and 2001 (cohorts born between 1951 and 1975), own calculations.

Note: For this graph we divided the cohorts differently between the censuses than elsewhere in the paper, as to minimize the influence of the larger proportion of missing educational data in the 2001 census. 
So, by the first cohorts born after World War II, women had almost caught up with men in secondary education. Universities still remained very male dominated until the late 1970s (Ronsijn, 2014, p. 214). Since the end of the 1990s women outnumber men in universities too, although there remains considerable gender segregation according to educational field - with many more women graduating in fields such as psychology and many more men in engineering, for example (Leplae, 2000). Of the men and women born in the 1970s, who completed their education towards the end of the century, $36 \%$ and $48 \%$, respectively, obtained a higher degree. Figure 1 shows that in these cohorts men and women were about as likely to obtain a university degree, but women outnumber men greatly in non-university tertiary education.

\section{Trends in the timing and likelihood of marriage}

The turnaround of the gender imbalance in education is quite remarkable and may have important implications for all kinds of demographic behaviour, including union formation (Van Bavel, 2012). Until well into the second half of the twentieth century, stable union formation was more or less synonymous with marriage in Belgium. However, marriage patterns have altered profoundly in the past two centuries. Marriage has become late and far from universal in Europe (Hajnal, 1965) since the Early Modern period (Seccombe, 1990). Yet, from 1850 onwards, the proportion of singles in the population decreased almost monotonically for over a century: where about $65 \%$ of the 25 to 29 year olds in 1850 where not married, this was only 15\% in 1970 (Lesthaeghe, 1977).

Figure 2 shows the proportion of ever married men and women before age 40 by birth cohort. Almost every subsequent generation born in the first half of the twentieth century married more frequently than the previous one. The increase of likelihood of marriage is very steady over the cohorts, with for example no visible impact of the second World War for generations reaching their twenties during the war. The tipping point is the Baby Boom generation: men and women born from the 1940s onwards are again less likely to be married by the age of 40 . The decline starts earlier for men than for women, most likely due to the fact that husbands tend to be about two to three years older than their wives. The divergence between men and women among the youngest cohorts seems surprisingly large. To double check this, we have also calculated directly the proportion of ever married men and women for the cohorts born in 
1941 and 1961. Since all ever married men in these cohorts where married before or by the age of 40 , which is the age they had at the time of the census, for these particular cohorts we do not need to impute age at marriage information to calculate the proportion of ever married men by the age of 40 . This alternative approach confirms our results. We find that $80 \%$ of men and $87 \%$ of women born in 1961 were ever married, and that $91 \%$ of men and $94 \%$ of women born in 1941 were ever married, which is very much in line with the results reported in Figure 2.

FIGURE 2 Proportion of men and women ever married by age 40 by birth cohort, 1910-1960

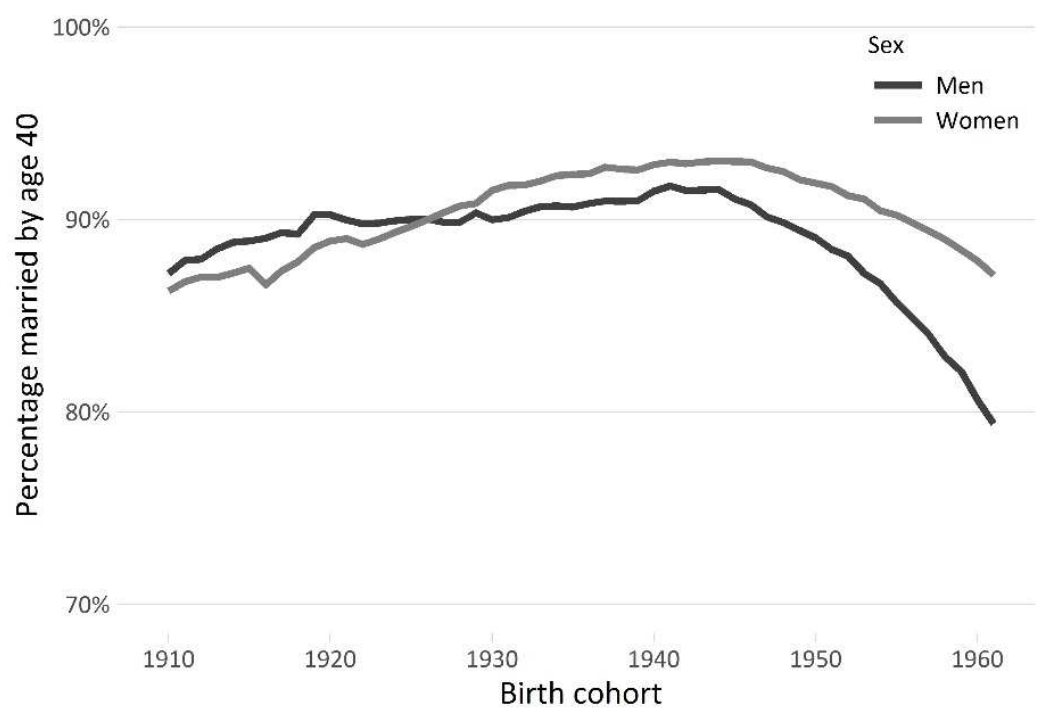

Source: Belgian censuses of 1981 and 2001, own calculations.

In Figure 3 the proportion of ever married men and women is split up by educational attainment. It is clear that the increase in likelihood of marriage among generations born in the first half of the century, is completely due to the higher educated, in particular higher educated women. Highly educated women born at the start of the century had a very high chance of remaining unmarried. Almost half of the women with a tertiary nonuniversity degree born in the 1910s remained unmarried, compared to about $10 \%$ of women with at most primary education. 
Figure 3 Proportion of men and women ever married by age 40 by birth cohort and education

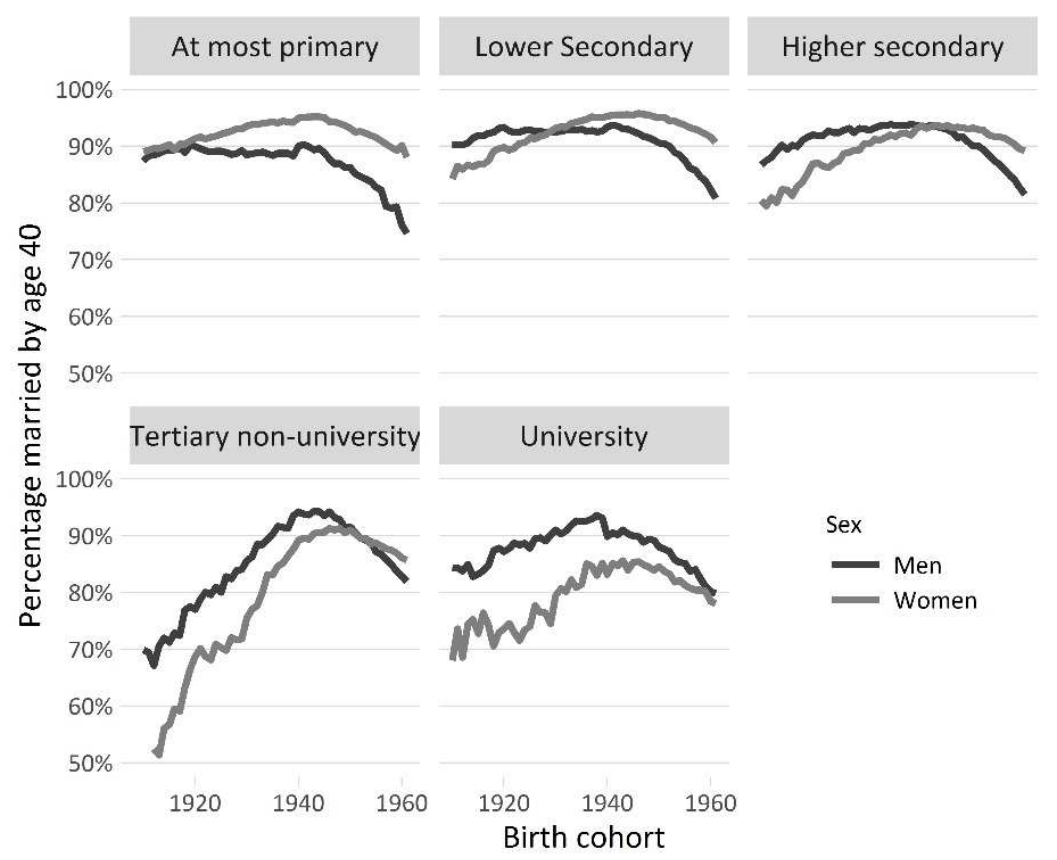

Source: Belgian censuses of 1981 and 2001, own calculations.

Not only did more people ever marry, they also married at a younger age. The age at first marriage decreased already a lot during the second half of the 19th century and the first half of the 20th century: between 1850 and 1900, it decreased by three years for men as well as for women, and it kept on declining in the following decades (Van de Walle, 1965). Cohort trends in ages at first marriage (Figure 3 ) show that the decrease of age at first marriage was indeed substantial and persisting. While the decrease was small or non-existent among the generations born in the 1910s, who reached their 20s in the worst years of the depression, among younger generations the decrease was accelerating again, with contrary to what may be expected no upswing for the generations that reached their twenties during World War II. Amongst birth cohorts of the first half of the 20th century age at first marriage dropped by more than three years. Strikingly, these trends notwithstanding, the mean age gap between husbands and wives remained quite stable over all those cohorts: throughout the 20th century, men were on average 2 to 2.5 years older than their wives in women's first marriages. 
Figure 4 Husband and wife's mean age at the time of the wife's first marriage, cohorts 1910-1965

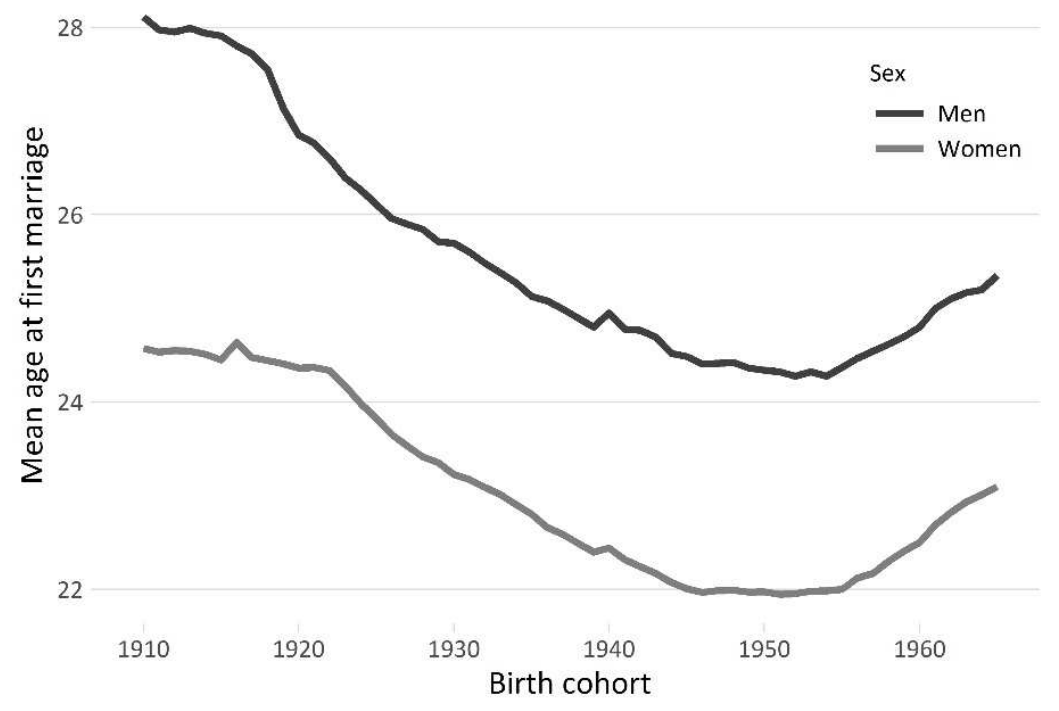

Source: Belgian censuses of 1981 and 2001, own calculations.

Figure 5 indicates that the decline of age at first marriage happened at all levels of educational attainment. The declining cohort trend reversed after the 1950 cohort; people born later started to marry at an older rather than a younger age. Here, too, we see a remarkable consistency across educational levels. Although women with no or very little education tend to marry younger than highly educated women, they started marrying later in the same cohorts and to the same extent as women with a university degree (compare the top left with the bottom right panel of Figure 5). The age difference between men and women decreases with educational attainment: tertiary educated men and women clearly differ less in age at first marriage than men and women with primary or secondary degrees.

The literature discusses several factors that could have played a role in the weakening of the Malthusian marriage pattern, both in the strong decline of the age at marriage and to a lesser extent in the rise of the proportions ever marrying. These trends go back to the 19th century, when economic modernization played a pivotal role. Industrialization permitted people to be economically independent at a younger age. New economic opportunities had implications for gender relations. The work place and the home were evolving into two «separate spheres», public and private, respectively. While men were increasingly expected to earn a family income in work places that were less often family - and home- 
based than in earlier times, women were gradually pushed out of the public sphere and into the private domain. Matthijs (2002) argues that they were expected to acquire status and self-esteem within the private family sphere by emphasizing their roles as wives and mothers. Hence, Matthijs (2003) considers that early and more universal marriage and identity construction based on family roles was a reaction to, as well as a remedy for, women's exclusion from the public sphere. This perspective implies that the qualitative change of marriage, i.e. the room that opened up for self-fulfilment and love (Coontz, 2005), was triggered by socio-economic modernization. In turn, this resulted in a quantitative shift, namely the change in marriage intensity and timing.

Figure 5 Husband and wife's mean age at first marriage of women by birth cohort and educational attainment

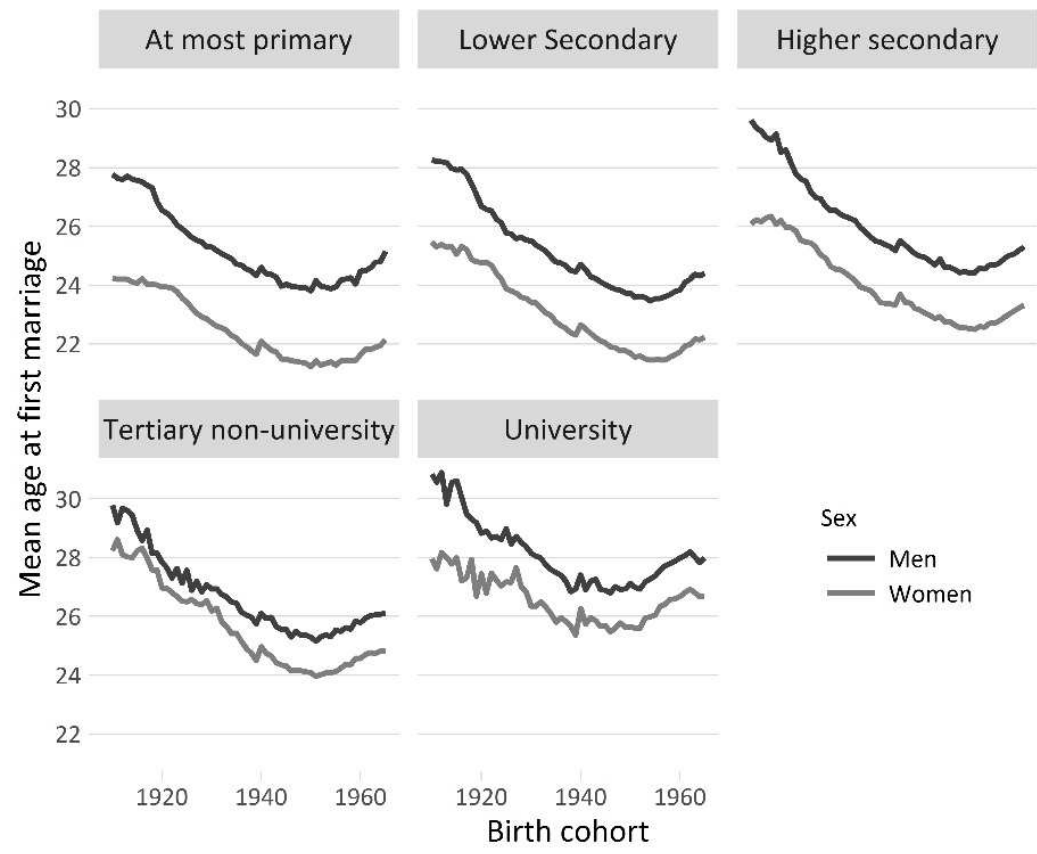

Source: Belgian censuses of 1981 and 2001, own calculations.

While the trends just outlined had their roots in the nineteenth century, there is an interesting analogy with later evolutions in the 20th century. Then, too, gender roles were on the move. If demographic behaviour in the second half of the 19th and early 20th century was accompanied by the exclusion of women from the public life, demographic behaviour in the second part of the 20th century was associated with a re-entrance of 
women in the world outside of their family-homes. The gradual re-entrance of women into the labour market together with their growing participation in education changed their relationship with men in general and with their husbands in particular. What is remarkable, however, is that this changing balance initially did not temper the decrease of the age at marriage and that, instead, the 1950s and 1960s became the golden age of marriage (Coontz, 2005). Even though women started to catch up in education, the division of labour within the family remained strongly gender based. The male breadwinner - female homemaker model, although still far from universal in practice, stood strong as a normative ideal. While in 1930 women made up about $26 \%$ of the Belgian labour force, this went down to 23\% in 1947 (Lambrechts, 1975). Relatively highly educated women who wanted to capitalize on their education in the labour market, had to sacrifice their marriage plans, if they had any. Women were supposed to leave the labour force once they got married (Witte et al., 1999). In fact, many viewed the redundancy of the wife's labour as an important social realization (Vandebroek, 2003). Even female teachers were obligated to quit their job in Catholic schools when they got married until as late as 1963 (Depaepe et al., 2004). It should not come as a surprise then that under such circumstances, highly educated women often remained unmarried.

From the 1950s onwards, female labour market participation started to rise again (Lambrechts, 1975). However, the growing participation of women in education and the labour market only started to undermine early and almost universal marriage in the last 30 years of the century (Goldscheider et al., 2015), when cohorts born after World War II started to reach their twenties. These were also the first generations of women who could take advantage of the efficient modern hormonal contraceptives (Goldin, Katz, 2002). As we have seen, it was the women of these cohorts that equalled and eventually surpassed the educational attainment of their male peers. Unmarried cohabitation became more prominent and allowed people to postpone their marriage, if they were to marry at all (Lesthaeghe, van de Kaa, 1986).

Since the late 1970s, unmarried cohabitation has indeed become gradually more common, having a hand in both higher ages at marriage and lower marriage intensities. Nevertheless, the majority of couples eventually still marry: Corijn and Matthijs (2004) estimated that the share of unmarried cohabitation in all household compositions has increased from about $2 \%$ in 1981, over $3 \%$ in 1991 to $7 \%$ in 2003 . The social acceptance of unmarried cohabitation allowed young people to postpone marriage (Matthijs, 1986) but the majority still marries in the end. Widowed and 
divorced people, on the other hand, remarry less often than they used to. Even if the majority of couples still marry eventually, the social meaning of marriage has changed. Marriage as an institution, as a bond sealed by church and state, has been replaced by a looser, companionate marriage, in which the independence of the individual is primordial (Lesthaeghe, van de Kaa, 1986).

\section{Who marries whom?}

Shifting gender relations have transformed marriage: after the emergence of the male breadwinner - female homemaker model, roughly between 1850 and 1950, there was the gradual re-entrance of women in the labour market and a growing participation in education in the second half of the 20th century. This section looks at how these trends were associated with shifting patterns of educational assortative mating in 20th century Belgium - who marries whom?

Rates of homogamy reflect the degree to which individuals with similar characteristics marry each other (Mare, 1991). Given the gender differences within the educational expansion, it is particularly interesting to look at educational assortative mating and how it connects with age at marriage and trends in age homogamy (Van de Putte et al., 2009). Education is a very relevant characteristic, because it strongly affects access to valuable resources. It is no coincidence that schools have served increasingly as a marriage market where potential partners meet (Blossfeld, 2009). As returns to schooling increase, men as well as women prefer partners with a similar or better educational attainment (Kalmijn, 1998). This effect is reinforced by the fact that people spend more time in the educational system too (Mare, 1991, 2014). Since schools are increasingly educationally homogeneous when you go up a level - primary school include both children who will leave school early and children who will move on to academic degrees later in life, while universities only include people at advanced levels of education - the odds to have a homogamous match increase with the level of educational attainment. Given these elements, we should expect then that homogamy rates have increased during the 20th century. 
FIGURE 6 Proportion of homogamous, hypergamous and hypogamous marriages by birth cohorts 1910-1975

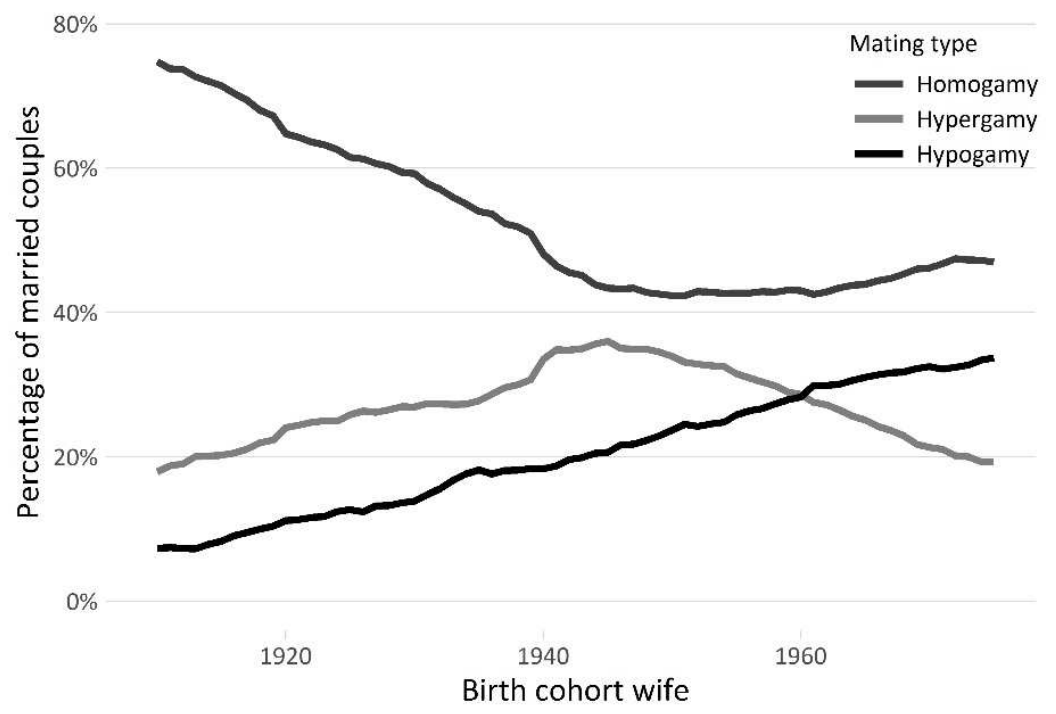

Source: Belgian censuses of 1981 (cohorts 1910-1939) and 2001 (cohorts 1940-1975), own calculations.

Note: Using the birth cohort of the husband instead just shifts the whole graph to the left, but preserves the patterns.

Figure 6 shows the proportion of educationally homogamous (spouses have the same educational attainment), hypergamous (the husband is higher educated than the wife) and hypogamous (the husband is lower educated than the wife) marriages for each birth cohort of the wife between 1910 and 1975. In all cohorts, homogamy remained most common, hypergamy coming next, and hypogamy the least common pattern until recent cohorts. Over the generations born before World War II, homogamy was on the decline, while both hyper- and hypogamy were getting increasingly more common. The expected rise of educational homogamy started only among cohorts born in the late 1940s and in the 1950s, who typically married during the 1970s. While homogamy reached its low point among cohorts born in the 1940s, hypergamy reached its high point, which is indicative of the popularity of the male breadwinner-female homemaker model in these generations. Yet, it should be noted that even among these cohorts hypogamy was far from unusual. Men born in 1944 married women with a lower educational level in $37 \%$ of the cases and women with a higher educational level in $21 \%$ of the cases. Among 
younger cohorts, hypergamy was on the decline, while hypogamy continued to become more common over the whole period, which resulted in more hypogamous marriages than hypergamous marriages in the most recent cohorts. Men born in 1975, who got married by the end of the century, married women with a higher educational level in $31 \%$ of the cases, while only in $18 \%$ of the cases the husband was higher educated than his wife, meaning that hypergamy among cohorts born in 1975 was in fact less common than hypogamy was among cohorts born in 1944. Summing up: while women tended to marry men who were at least as highly educated as themselves until the 1950s cohorts, in more recent cohort, women have tended to marry men who are at most as highly educated as themselves. This means that the traditional pattern of hypergamy has evaporated (in line with an international trend, see Esteve et al., 2016).

In Figure 7, homogamous couples are divided in low educated homogamous couples (both partners have at most a primary degree) and medium to highly educated homogamous couples (both partners have a lower secondary degree or better). These two groups are very different: the one is a relic of the past, possibly fuelled for a while by the large group of mostly low educated immigrants coming to Belgium after the war, but quickly disappearing towards the younger cohorts; the other is indeed becoming the dominant pattern at the end of the century. In general, Figure 7 shows clearly how the expansion of education participation shifted educational assortative mating patterns from homogamous couples with very little education to couples where at least one partner has a secondary or, especially among the youngest cohorts, a tertiary degree.

Figure 8 shows the proportions of homogamous marriages for birth cohorts between 1900 and 1970 for each category of educational attainment of the husband. Figure 9 shows the same for each category of educational attainment of the wife. In the bottom right corner of Figure 8, we see that men with a university degree born in the 1970 s have a much bigger chance to have a partner with an equally high educational attainment than men born in the 1910s. This should not come as a surprise, given the fact that women with a university degree were in very short supply in the generations born at the beginning of the century: even if university educated men born in the 1910s would have wanted to marry homogamously, most of them would not have been able to do so. We also see quite large increases for men with a lower-secondary, higher-secondary and tertiary non-university education: later generations ended up with a partner of similar educational attainment more and more. The younger cohorts of the lower educated, in contrast, are decreasingly married homogamously. 
FigURE 7 The disappearance of low educated homogamy, birth cohorts 1910-1975

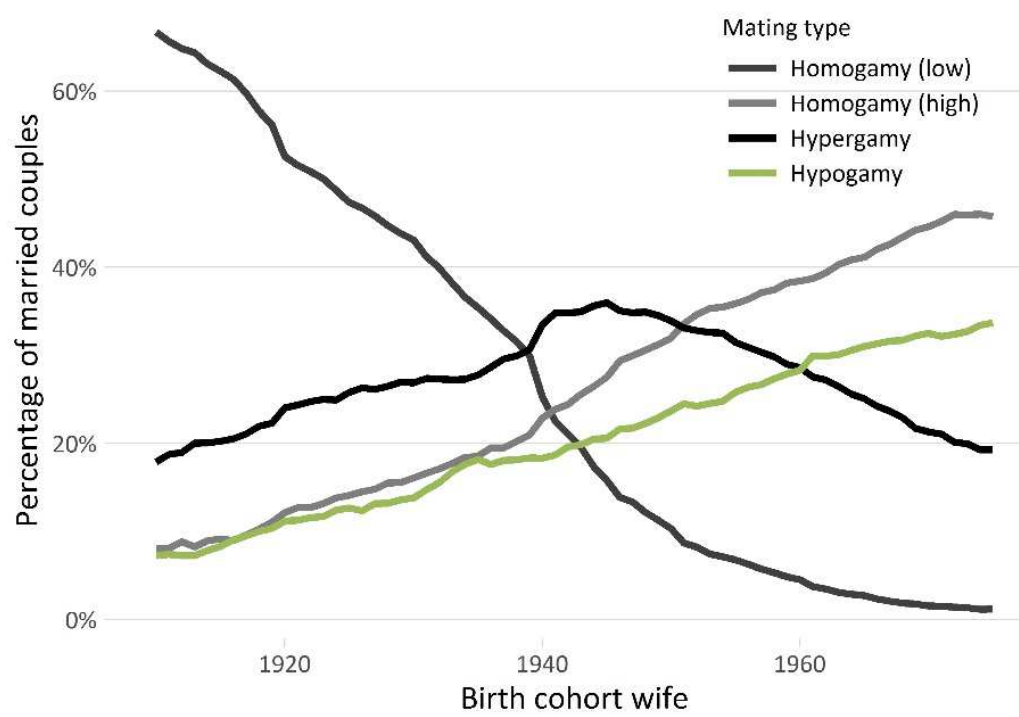

Source: Belgian censuses of 1981 (cohorts 1910-1939) and 2001 (cohorts 1940-1975), own calculations.

FIGURE 8 Proportion of homogamous marriages by cohorts 1910-1975 by male educational attainment

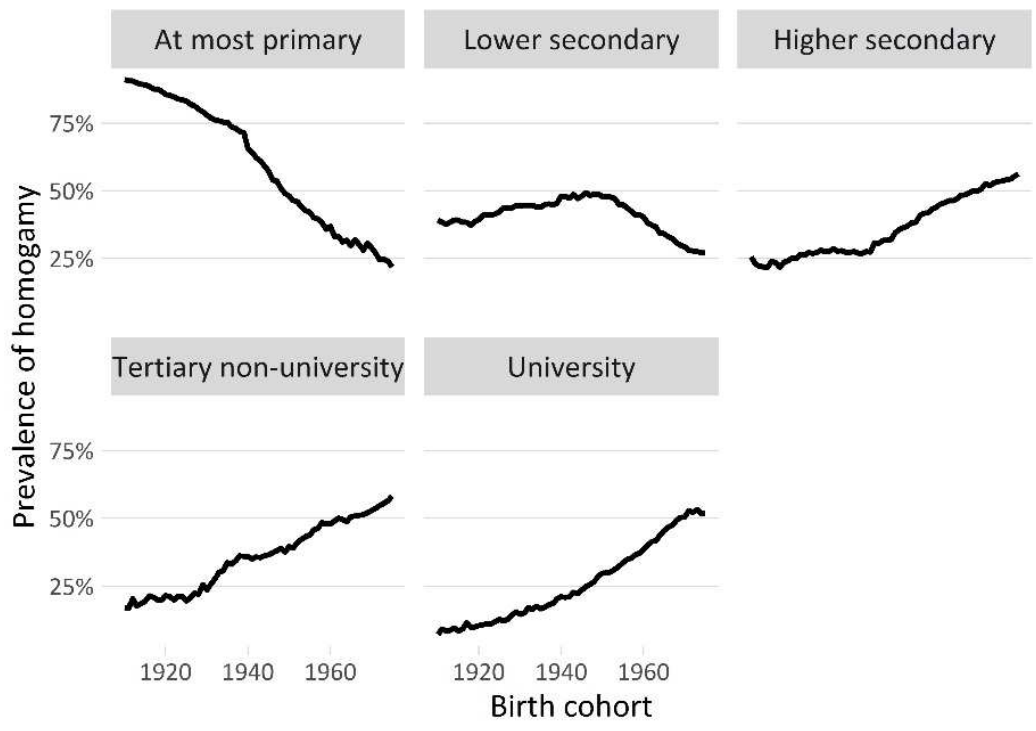

Source: Belgian censuses of 1981 and 2001, own calculations. 
In the bottom right corner of Figure 9, we see that the few women born in early 1900s with a university degree had a very high chance of being married homogamously, if they married at all. The proportion marrying homogamously decreased slightly in the younger generations of women. Women with a non-university tertiary degree, mainly school teachers and nurses, did not end up with a homogamous partner very often, however. Again, this is not surprising given the fact that they greatly outnumbered men in this category.

FIGURE 9 Proportion of homogamous marriages by cohorts $1910-1975$ by female educational attainment

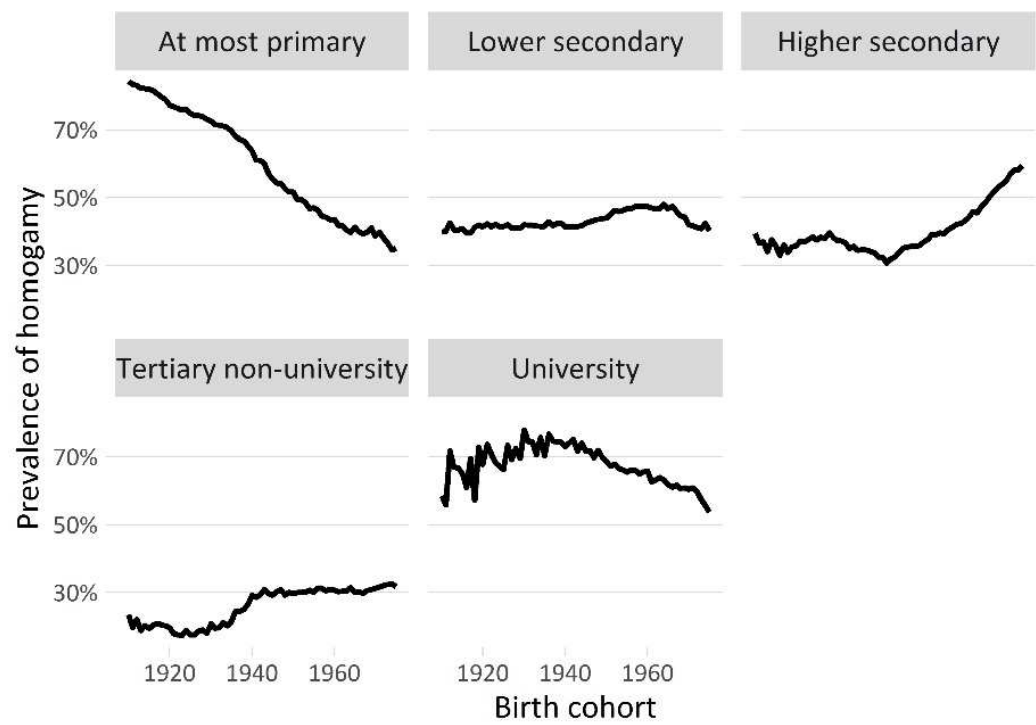

Source: Belgian censuses of 1981 and 2001, own calculations.

The fact that in absolute terms there was a larger surplus of medium to highly educated men among the generation born in the interwar period, who were forced to marry hypergamous even if they would have preferred differently, suggest that the patterns of educational assortative mating we described are mainly a matter of the changing marginal distribution of education, rather than changing preferences or tendencies. We use a log-linear model to shed some light on this issue.

The diagonal term in our log-linear model, $\delta_{i j t}$ can be interpreted as the odds that both spouses belong to the same educational category or, in other words, the odds that a couple is on the diagonal rather than not, 
after taking into account the marginal distributions of educational attainment of both partners. The estimates for these odds, plotted in Figure 10, show that the tendency for homogamy is stronger in the more "extreme» educational categories compared to the categories in between, which is unsurprising given that marital options in the extreme categories are restricted in just one direction (Esteve, Cortina, 2006).

\section{FIGURE 10 Estimates of the diagonal term $\delta_{i j t}$} of the log-linear model when $i=j$

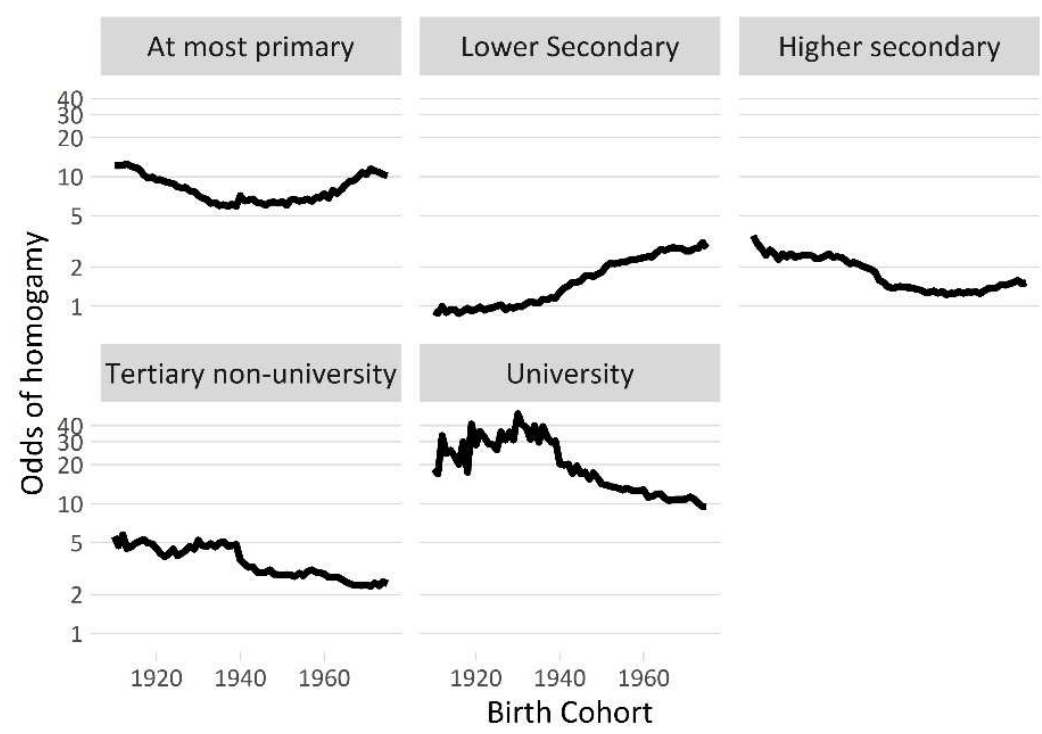

Source: Belgian censuses 1981 and 2001, own calculations.

There is tendency to marry homogamously across all educational levels, but it was especially high among the university educated, especially among the older cohorts. The log-linear model shows that university educated men in these cohorts indeed exhibited a strong inclination to marry an equally high educated woman, but since they were in short supply, the proportion of homogamously married university educated men remained low. In the other educational categories, the tendency to marry homogamously was going down over the cohorts, except for those with a lower secondary degree. Among the latter, the odds were rather low to begin with. For the younger cohorts we have a bit more of a mixed picture. Towards the youngest cohorts, homogamy seems to have been on the rise among the lower educated, but it is decreasing among the higher educated. 
Finally, we look at the association between assortative mating and the timing of marriage. Oppenheimer (1988) argued that trends in marriage timing result, in part, from variations in the degrees of difficulty people encounter in mating assortatively. Do people who find a partner with a similar educational attainment marry sooner or later than those who do not? Figure 11 plots the evolution of the wife's average age at first marriage over the cohorts by the type of educational assortative mating. Homogamous marriages between low educated partners happen on average at the youngest age, and this does not change at all over the different cohorts. Hypergamous couples are a rather distant second, but happen on average substantially earlier than medium to high educated homogamous marriages and especially hypogamous marriages, in particular among the oldest cohorts.

FIGURE 11 Wife's age at first marriage by assortative mating type, her educational attainment and birth cohort, 1910-1965

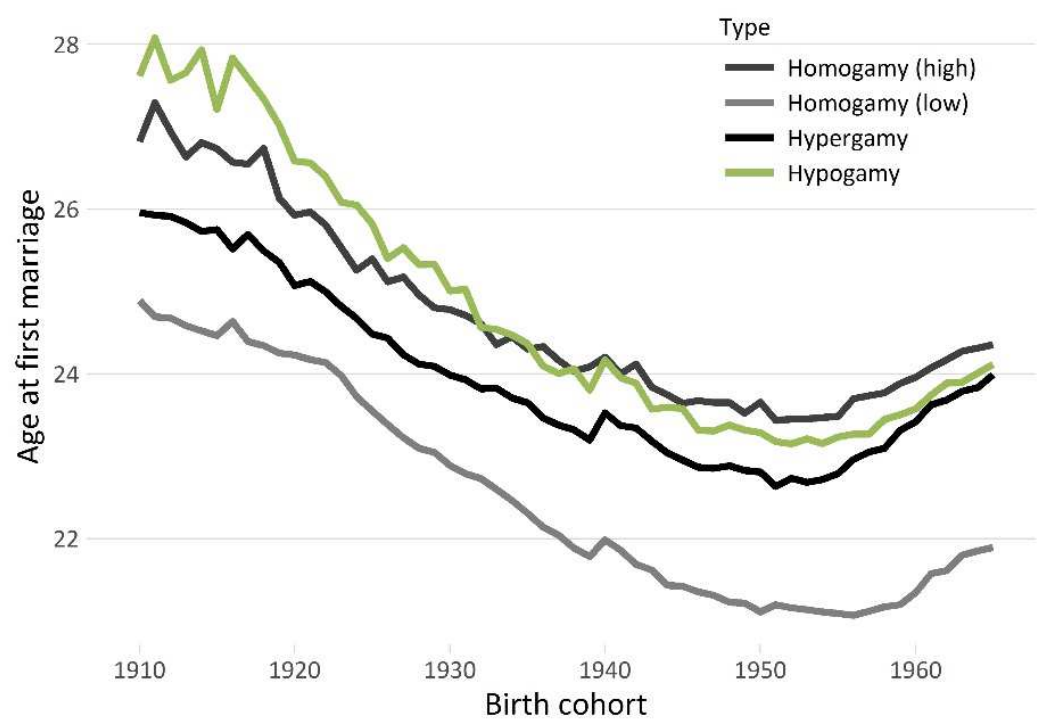

Source: Belgian censuses of 1981(cohorts 1900-1929) and 2001 (cohorts 1930-1975), own calculations.

A straigthforward explanation for much of the variation that we see is the fact that attaining a higher degree takes time, so we can expect that a marriage with at least one high educated partner will take more time than a homogamous marriage between low educated partners. Indeed, the pattern emerging among the youngest cohorts is perfectly in line with this explanation. However, it does not explain the difference between 
hypergamous and hypogamous marriages among the older cohorts. One explanation might be that the combinations common to hypergamy are different than the combinations common to hypogamy. However, we have seen that university educated men mostly married hypergamously, and most university educated women married homogamously, which in fact means that the husbands in hypergamous couples spent more time in school than the wives in hypogamous couples. Therefore it seems likely that the difficulties to get married that higher educated women experienced in this era must be decisive, especially when they did not succeed in finding an equally or even higher educated partner.

\section{Discussion and conclusion}

During the 20th century, marriage patterns in Belgium have changed in several dimensions. In the first half of the century, age at women's first marriage was declining equally among all educational groups. The age difference between husband and wife at first marriage remained very stable, larger for the low educated than for the highly educated. The likelihood of marriage was increasing, especially among the highly educated. High educated women in particular, who were very unlikely to get married among the oldest cohorts, were catching up. This culminated in the «golden age» of marriage in the first decades after World War II. Among the generations born right after World War II, reaching their twenties in the late 1960s or 1970s, both the trend of declining age at marriage and the one of increasing likelihood of marriage were reversed. Regardless of their educational attainment, people started to postpone marriage again, as unmarried cohabitation became a viable alternative. People also again were becoming less likely to get married. Among the youngest cohorts, highly educated women are no longer the least likely to get married. Instead it is the low educated men who remain unmarried the most, a turnaround that testifies of the changing gender balance in education and on the labour market. Moreover, the traditional institution of marriage, maintained by church and state, was more and more replaced by a looser, companionate marriage, resulting in increasing divorce rates and decreasing numbers of church celebrated marriages.

The education expansion and the changing gender balance in educational attainment transformed patterns of assortative mating. Here too, there is a difference between the first and second half of the century. There is a clear decrease of the prevalence of homogamy among the older cohorts, 
but this is all due to the low educated couples. The tendency to marry homogamously was very high among the university educated, according to our log-linear model, but since university educated women were scarce, most university educated men had to marry down. One could interpret the general decline of homogamy as the weakening of social class barriers in a more heterogeneous and more open society, stimulated by the expanding education of the population. Nevertheless, we cannot equate educational heterogamy with heterogamy in terms of social class. In order to find that out, one would have to take into account social class indicators of the parents of husbands and wives, too. An alternative interpretation of increasing heterogamy in the older generations is that education became more important for men in the labour market while such was not yet the case for women, due to the separation of breadwinning and homemaking in an industrialising society. The increase of hypergamy among cohorts born before World War II, resulting in a peak of hypergamy among cohorts born in the 1940s, is consistent with this view.

Among the younger cohorts, hypergamy is dwindling, being surpassed both by homogamy and hypogamy. In a remarkable turnaround, women, who tended to marry men who were at least as highly educated as themselves until the 1950s cohorts, are now more likely to marry men who are at most as highly educated as themselves. Educational homogamy, marriages between two equally highly educated partners, nevertheless prevails as the dominant pattern. Yet, our log linear model suggests that this increase was mainly due to changes in the marginal distribution of educational attainment; that is, by the fact that women's educational attainment grew faster than men's. As opposed to some studies in other countries (most notably the U.S., see Schwartz and Mare, 2005), we do not find a pronounced increase of homogamy among the highly educated marrying in the second half of the century. Our findings are more in line with Schmidt \& Winter (2008), who find that tendency of marrying homogamously is more or less stable in Germany among the highly educated in the last decades of the 20th century, corresponding in our case with the cohorts born between 1950 and 1975 .

We have furthermore presented some data about how these trends in assortative mating are linked with trends in marriage timing. One interesting finding is that hypogamous marriages tend to happen between spouses who are older than their peers marrying homogamously or hypergamously. Selectivity is likely to play a role here: women who opted for more education might have been less interested in marriage and family life than those who left school earlier. If they did want to get married, however, they might have experienced a disadvantaged position at the 
marriage market. Oppenheimer (1988) argued that trends in marriage timing result, in part, from variations in the degrees of difficulty people encounter in mating assortatively. Assortative mating is hindered by a relatively high degree of uncertainty about the important attributes that people attempt to match and, as a result, marriages are delayed. This could explain some of the observed timing patterns. Especially among older cohorts, highly educated women were likely to have more unstable career prospects, and were possibly perceived to have less clear expectations regarding marriage, both of which increased uncertainty and as such on average the time it took them to find a marriage partner.

While Oppenheimer's theory is tested and confirmed on contemporary case studies of men with uncertain economic prospects (see for example Kalmijn, 2011), it is still an open question whether the theory can provide a framework for analysing historical data. While the transformation of women's economic roles, which Oppenheimer sees as the cause of greater delays in marriage in contemporary society, has greatly accelerated in the most recent decades, the roots of these changes are to be found in the middle of the 20th century. The education expansion, the gradual re-entrance of women in the public world and the convergence of gender roles had an influence (1) on patterns of assortative mating, (2) on the preferences for finding a similar partner and (3) on the difficulty of finding such a partner and (4) thus, if Oppenheimer is right, on the timing and incidence of marriage. As we have seen, the age at first marriage kept declining at a steady pace until the 1970s. If at this time assortative mating was getting easier, Oppenheimer's theory could offer a plausible explanation for this decline. Conversely, if assortative mating was becoming more difficult as a result of the changing gender balance and the converging marriage preferences of men and women from the 1970s onwards, this would result in longer «trial» periods of unmarried cohabitation and an increasing age at marriage. A future, more thorough analysis should shed more light on this possible mechanism and on the validity of Oppenheimer's theory to explain the changing nuptiality patterns described in this paper.

\section{Acknowledgements}

The research leading to these results has received funding from the European Research Council under the European Union's Seventh Framework Programme (FP/2007-2013)/ERC Grant Agreement no. 312290 for the GENDERBALL project. This paper benefited from the comments we 
received when we presented an early version at the Social Science History Association Annual Meeting of 2015.

\section{References}

Agresti A. (2002), Categorical Data Analysis, Hoboken, John Wiley \& Sons, https:// doi.org/10.1002/0471249688.

Ballarino G., Meschi E., Scervini F. (2013), The Expansion of Education in Europe in the 20th Century, GINI Discussion Paper 83.

BARRO R., LEE J. (2001), «International Data on Educational Attainment: Updates and Implications», Oxford Economic Papers, 53 (3), pp. 541-563, https://doi.org/10. 1093/oep/53.3.541.

BiRKelund G. E., HeLdAL J. (2003), «Who Marries Whom? Educational Homogamy in Norway», Demographic Research, 8, pp.1-30, https://doi.org/10.4054/DemRes. 2003.8.1.

BLOssfeld G. J. (2014), «Educational Assortative Mating and Divorce: A Longitudinal Analysis of the Influences of Education on the Divorce Rate for Different Educational Matches", Paper Presented at the Annual Meeting of the Population Association of America.

BLossfeld H.-P. (2009), «Educational Assortative Marriage in Comparative Perspective», Annual Review of Sociology, 35 (1), pp. 513-530, https://doi.org/10.1146/ annurev-soc-070308-115913.

Botterman S., Hooghe M. (2012), "Religion and Voting Behaviour in Belgium: An Analysis of the Relation Between Religious Beliefs and Christian Democratic Voting», Acta Politica, 47, pp. 1-17, https://doi.org/10.1057/ap.2011.11.

Bozon M. (1991), «Le choix du conjoint», F. DE SINGLY (ed), La famille. L'état des savoirs, Paris, La Découverte, pp. 22-33.

BreEN R. (2010), "Educational Expansion and Social Mobility in the 20th Century», Social Forces, 89 (2), pp. 365-388, https://doi.org/10.1353/sof.2010.0076.

BUKOdi E., GoldthORPE J. H. (2012), «Decomposing 'Social Origins': The Effects of Parents' Class, Status, and Education on the Educational Attainment of Their Children», European Sociological Review, 29 (5), pp. 1'024-1'039.

COHEN D., Sото M. (2001), "Growth and Human Capital: Good Data, Good Results», CEPR Discussion Paper, $3^{\prime} 025$.

Coontz S. (2005), Marriage, a History: From Obedience to Intimacy, or How Love Conquered Marriage, New York, Viking. 
CoRIJn M., MATthiJs K. (2004), Gehuwd En Ongehuwd Samenwonen in België. Een Sociaal-Demografisch Perspectief, Leuven, Departement Sociologie, K.U.Leuven, (Onderzoeksverslag van het Departement Sociologie, Afdeling voor Gezin, Bevolking en Gezondheidszorg GB/2004-28).

De VRoede M. (1970), "De Weg naar de Algemene Leerplicht in België», Bijdragen en Mededelingen Betreffende de Geschiedenis der Nederlanden, 85, pp.141-166, https://doi.org/10.18352/bmgn-lchr.1616.

Deboosere P., Willaert D. (2004), «Codeboek Algemene Socio-Economische Enquête 2001», Working Papers Steunpunt Demografie.

Depaepe M., Lauwers H., Simon F. (2004), «De Feminisering van het Leerkrachtencorps in België in de Negentiende en de Twintigste Eeuw», Revue Belge de Philologie et d'Histoire - Histoire Médiévale, Moderne et Contemporaine, 82 (4), pp. 969-994.

DuChesne I., Nonneman W. (1998), "The Demand for Higher Education in Belgium», Economics of Education Review, 17 (2), pp. 211-218, https://doi.org/10.1016/S02727757(97)00024-1.

Esteve A., Cortina C. (2006), "Changes in Educational Assortative Among in Contemporary Spain», Demographic Research, 14, pp. 405-428, https://doi.org/10.4054/ DemRes.2006.14.17.

Esteve A., Schwartz C., Van Bavel J., Permanyer I., Klesment M., Garcia J. (2016), "The End of Hypergamy: Global Trends and Implications», Population and Development Review, 42, https://doi.org/10.1111/padr.12012.

Frimmel W., Halla M., Winter-Ebmer R. (2013), «Assortative Mating and Divorce: Evidence from Austrian Register Data", Journal of the Royal Statistical Society, Series A, Statistics in Society, 176 (4'446), pp. 907-929.

Gadeyne S., Deboosere P. (2002), «De Ultieme Ongelijkheid: Sterfteverschillen bij Belgische Mannen en Vrouwen naar Socio-Economische Karakteristieken en Huishoudenstype», Belgisch Tijdschrift Voor Sociale Zekerheid, 1, pp. 57-101.

GLASS D. (1954), Social Mobility in Britain, London, Routledge \& Kegan Paul.

Goldin C., KATZ L. F. (2002), «The Power of the Pill: Oral Contraceptives and Women's Career and Marriage Decisions», Journal of Political Economy, 110 (4), pp. 730-770, https://doi.org/10.1086/340778.

Goldscheider F., Bernhardt E., LAPPegard T. (2015), «The Gender Revolution: A Framework for Understanding Changing Family and Demographic Behavior», Population and Development Review, 41 (2), pp. 207-239, https://doi.org/10.1111/j. 1728-4457.2015.00045.x.

Grow A., Van Bavel J. (2015), «Assortative Mating and the Reversal of Gender Inequality in Education in Europe: An Agent-Based Model», PLoS ONE, 10 (6), pp. 1-24, https://doi.org/10.1371/journal.pone.0127806. 
Hajnal J. (1965), "European Marriage Patterns in Perspective», D. V. Glass, D. E. C. EVERSLEY (eds), Population and History. Essays in Historical Demography, London, Edward Arnold, pp. 101-143.

KAelble H. (1981), Historical Research on Social Mobility. Western Europe and the USA in the Nineteenth and Twentieth Centuries, New York, Columbia University Press.

JANSSENS A. (1997), "The Rise and Decline of the Male Breadwinner Family? An Overview of the Debate», International Review of Social History, 42 (S5), pp. 1-23.

KaLMIJN M. (1991), «Shifting Boundaries: Trends in Religious and Educational Homogamy», American Sociological Review, 56 (6), pp. 786-800, https://doi.org/10.2307/ 2096256.

KALMijn M. (1998), "Intermarriage and Homogamy: Causes, Patterns, Trends», Annual Review of Sociology, 24, pp. 395-421, https://doi.org/10.1146/annurev.soc.24. 1.395 .

KALMIJN M. (2011), «The Influence of Men's Income and Employment on Marriage and Cohabitation: Testing Oppenheimer's Theory in Europe», European Journal of Population, 27, pp. 269-293, https://doi.org/10.1007/s10680-011-9238-x.

LAMBRECHTS E. (1975), Vrouwenarbeid in Belgie: Een Analyse van het Tewerkstellingsbeleid Inzake Vrouwelijke Arbeidskrachten sinds 1930, Leuven, Centrum voor Bevolkings en Gezinsstudiën.

LEPLAE J. (2000), "Vrouwen in de Academische Wereld», RoSa-factsheet, 2, www. rosadoc.be/pdf/factsheets/nr2.pdf.

LeSthAeghe R. (1977), The Decline of Belgian Fertility, 1800-1970, Princeton (N. J.), Princeton University Press.

LeSthaeghe R., VAN DE KAA D.J. (1986), "Twee Demografische Transities?», R. LESTHAEGHE, D. J. VAN DE KAA (eds), Bevolking: Groei En Krimp, Boekaflevering Van Mens \& Maatschappij, 61, Deventer, Van Loghum Slaterus, pp. 9-24.

LÉvi-Strauss C. (1956), "The Family», H. L. Shapiro (ed), Man, Culture and Society, New York, Oxford University Press, pp. 261-285.

LIU H., Lu J. (2006), "Measuring the Degree of Assortative Mating», Economics Letters, 92, pp. 317-322, https://doi.org/10.1016/j.econlet.2006.03.010.

Lutz W., Crespo Cuaresma J., SANDerson W. (2008), «The Demography of Educational Attainment and Economic Growth», Science, 319 (5'866), pp. 1'047-1'048.

Lutz W., Goujon A., SAMIR K. C., SANDERSON W. (2007), «Reconstruction of Population by Age, Sex and Level of Educational Attainment of 120 Countries for 1970-2000», Vienna Yearbook of Population Research, pp. 193-235, https://doi.org/10.1553/ populationyearbook2007s193.

MÄENPÄÄ E. (2014), "Homogamy in Educational Level and Parental Social Class in Finland: A Log-Linear Analysis», European Sociological Review, pp. 1-15. 
MARE R. D. (1991), "Five Decades of Educational Assortative Mating», American Sociological Review, 56 (1), pp. 15-32, https://doi.org/10.2307/2095670.

MARE R. D. (2014), Educational Assortative Mating in Two Generations : Trends and Patterns Across Two Gilded Ages.

MAтTHIJs K. (1986), Hertrouw in België. Een Sociaal-Demografisch Profiel Van Recente Ontwikkelingen, Leuven, Sociologisch Onderzoeksinstituut.

MatтHiJs K. (2001), «De Mateloze Negentiende Eeuw», Bevolking, Huwelijk, Gezin en Sociale Verandering, Leuven, Universitaire Pers Leuven.

MATTHIJS K. (2002), «Mimetic Appetite for Marriage in Nineteenth-Century Flanders: Gender Disadvantage as an Incentive for Social Change», Journal of Family History, 27 (2), pp. 101-127, https://doi.org/10.1177/036319900202700203.

MATtHIJS K. (2003), «Demographic and Sociological Indicators of Privatisation of Marriage in the 19th Century in Flanders», European Journal of Population, 19 (3), pp. 375-412, https://doi.org/10.1023/A:1026361006200.

Meyer J. W., RamiRez F. O., Nuhoglu Soysal Y. (1992), «World Expansion of Mass Education, 1870-1980», Sociology of Education, 65 (2), pp. 128-49, https://doi.org/10. 2307/2112679.

OPPENHEIMER V. K. (1988), "A Theory of Marriage Timing», American Journal of Sociology, 94 (3), $563 \mathrm{p}$.

RoNsIJn W. (2014), «Educational Expansion and Gender Inequality in Belgium in the Twentieth Century», Histoire \& Mesure, 29 (1), pp. 195-218, https://doi.org/ 10.4000/histoiremesure.4998.

SCHMIDT C. M., WinteR B. S. (2008), The Dynamics of Assortative Mating in Germany, Bochum, Ruhr Economic Papers, 346.

SCHOfER E., MeYer J. W. (2005), "The Worldwide Expansion of Higher Education in the Twentieth Century", American Sociological Review, 70 (6), pp. 898-920, https://doi. org/10.1177/000312240507000602.

SCHWARTz C. R. (2013), «Trends and Variation in Assortative Mating: Causes and Consequences», Annual Review of Sociology, 39 (1), pp. 451-470, https://doi.org/10. 1146/annurev-soc-071312-145544.

SCHWARTZ C. R., MARE R. D. (2012), "The Proximate Determinants of Educational Homogamy: The Effects of First Marriage, Marital Dissolution, Remarriage, and Educational Upgrading», Demography, 49 (2), pp.629-650, https://doi.org/10.1007/ s13524-012-0093-0.

Seccombe W. (1990), "The Western European Marriage Pattern in Historical Perspective: A Response to David Levine», The Journal of Historical Sociology, 3 (1), pp. 5074, https://doi.org/10.1111/j.1467-6443.1990.tb00145.x.

Shavit Y., Blossfeld H. (eds) (1993), Persistent Inequality: Changing Educational Attainment in Thirteen Countries, Boulder, CO, Westview Press. 
VAN BAVEL J. (2012), "The Reversal of Gender Inequality in Education, Union Formation and Fertility in Europe», Vienna Yearbook of Population Research, 10, pp. 127154, https://doi.org/10.1553/populationyearbook2012s127.

Van Bavel J. (2013), "Studying Social Differentials in the Mid- Twentieth Century Baby Boom from Retrospective Census Data», Paper Presented at the Annual Meeting of the Population Association of America, New Orleans.

VAN De PutTe B. (2005), Partnerkeuze in de 19de Eeuw. Klasse, Romantiek, Geografische Afkomst en de Vorming van Sociale Groepen op de Huwelijksmarkt, Leuven, Universitaire Pers Leuven.

Van de Putte B., Van Poppel F., Vanassche S., Sanchez M., Jidkova S., Eeckhout M., Oris M., Matthiss K. (2009), "The Rise of Age Homogamy in 19th Century Western Europe», Journal of Marriage and Family, 71 (5), pp. 1'234-1'253.

VAN DE WALLE E. (1965), "La nuptialité en Belgique de 1846 à 1930 et sa relation avec le déclin de la fécondité», Population et Famille, (6-7), pp. 37-56.

Van Leeuwen M. H. D., MaAs I., Miles A. (eds) (2005), Marriage Choices and Class Boundaries: Social Endogamy in History, Cambridge, Cambridge University Press.

VANDEBROEK H. (2003), «Gehuwd en Werkloos? Opvattingen over Vrouwenarbeid en Vrouwenwerkloosheid in Belgische Katholieke Intellectuele Kringen (1945-1960)», Belgisch Tijdschrift Voor Nieuwste Geschiedenis, 33 (1-2), pp. 215-258.

VANDERStRAeten R. (1996), "Analyse van de Participatie aan Onderwijs in België», Tijdschrift voor Sociologie, 17 (4), pp. 463-477.

VANDERStRAeten R., LOUCKX K., VAN DER GUCHT F. (2001), Education and Geographical differences.

VINCENT-LANCRIN S. (2008), "The Reversal of Gender Inequalities in Higher Education: An Ongoing Trend, in OECD Higher Education to 2030», Demography, 1, Paris, OECD, pp. 265-298, https://doi.org/10.1787/9789264040663-11-en.

WATtelar C., WUNSCh G. (eds) (1967), Étude démographique de la nuptialité en Belgique, Louvain, Université catholique de Louvain.

Weber M. (1974) [1946], "Class, Status, Party», J. Lopreato, L. LeWIS (eds), Social Stratification: A Reader, New York, Harper \& Row, pp. 45-54.

Willaert D., Deboosere P. (2008), «Codeboek Volkstelling 1/3/1981», Interface Demography Working Paper.

Witte E., De Groof J., Tyssens J. (eds) (1999), Het Schoolpact van 1958. Ontstaan, Grondlijnen en Toepassing van een Belgisch Compromis, Brussel, Garant. 